\title{
Avoiding Zoom Fatigue: The Uses and Gratifications on Social Media
}

\author{
Festy Rahma Hidayatia,1," and Irwansyah ${ }^{\mathrm{b}, 2}$ \\ a, bUniversitas Indonesia \\ Email: ${ }^{1}$ festy.rahma@ui.ac.id*; ${ }^{2}$ irwansyah09@ui.ac.id \\ *corresponding author
}

Keywords:

Uses and Gratification

Theory, Computer-Mediated

Communication (CMC), Social

Media, working from home, Zoom

Fatigue, Covid-19

\begin{abstract}
The Corona Virus Disease 2019 (Covid-19) pandemic has forced the government to implement Large-Scale Social Restrictions (PSBB) several times. As a result of this policy, it is mandatory to implement the Working From Home (WFH) policy. The company then facilitates its employee with virtual meeting applications, such as Zoom. On the other hand, WFH has a frequent impact and the length of time spent in virtual meetings causes zoom fatigue. The purpose of this study is to determine the uses and gratification of social media users to avoid zoom fatigue when working from home during the Covid-19 pandemic. Social media users use it as a means of fulfilling usability and satisfaction based on the media chosen. This study will describe the uses and gratification of using social media during WFH to avoid "Zoom fatigue" based on Computer-Mediated Communication Theory and Uses and Gratification Theory. The study uses a qualitative approach with an explorative method to find or formulate problems from a phenomenon. The study uses literature studies based on scientific articles in international and national journals related to the use of social media based on the Uses and Gratification theory in the last ten years. For further exploration, the researcher conducted in-depth semi-structured interviews via email and telephone with three informants. The interview results revealed the uses and gratification for social media users to avoid zoom fatigue while undergoing WFH during the pandemic Covid-19. Social media as a source of entertainment and relaxation, a source of information, spending time, interacting and expressing opinions, and monitoring. The researcher hopes that the results of this study can fill the lack of existing research related to the uses and gratification of social media based on Computer-Mediated Communication and Uses and Gratification Theory. It can also contribute knowledge to practitioners who are content creators, marketing agencies, and online shop owners to optimize content to get high user engagement.
\end{abstract}

Copyright (C) 2021 Channel Jurnal Komunikasi. All right reserved.

\section{INTRODUCTION}

The Covid-19 pandemic is increasingly widespread in various countries in the world. Indonesia just announced its first case on March 2, 2020. Based on data from the Covid-19 Handling Task Force on Saturday, January 9, 2021, there were 818,386 cases (Detik.com, 2021). The surge in Covid-19 cases made the government issue Large-scale Social Restrictions (PSBB) by referring to Government Regulation of Republic of Indonesia No.21 of 2020.

Large-scale Social Restrictions (PSBB) in Java and Bali were implemented from 11 to 25 January 2021. As a result of this policy, $75 \%$ of the working from home (WFH) is mandatory. The implementation of WFH is not the first time this has been carried out during the Covid-19 pandemic. The Covid-19 pandemic has forced organizations or companies to transform and innovate by using information and communication technology to maintain their business (Yogesh K. Dwivedi, 2020). There are currently increasing efforts to shift from "conventional" office settings to working from home (WFH) arrangements supported by information and communication technology, also referred to as telecommuting, telework, or remote work (Van der Lippe and Lippenyi, 2020). 
WFH-related studies show that employees spend more time working, which is about an extra hour per day, than when in the home. National Bureau of Economic Research explained that workers who undergo WFH spend around 49 additional minutes per day than office hours during normal conditions (CNNIndonesia, 2020). The longer working hours is because, during WFH, workers attend more virtual meetings and more e-mail. For optimal results, the company facilitates virtual meeting applications, such as Zoom. The option to zoom meetings for a full day during working hours or even over working hours results in "zoom fatigue." Full-day online meeting is the most common form of negative experience through prolonged use of the Computer-Mediated Communication (CMC) platform (Nadler, 2020).

Before the pandemic, Zoom was almost unknown to the public even though it had been around for nine years. However, in the last few months, Zoom's subscribers have multiplied. In fact, in the third quarter of 2020, Zoom reported revenues of 777.2 million US dollars. This number is up four times over the same quarter last year. Zoom's total net profit in the third quarter was 198.4 million US dollars (Stephanie, 2020). Apart from Zoom shows other options like Microsoft Skype, Apple Facetime, and Google Meet.

The activity restriction policy requires someone to stay at home to prevent the spread of Covid-19. Internet users increased during the pandemic by around 40 percent (CNNIndonesia, 2020). Based on the report "Indonesia: The Challenge of Monetizing in a Fast-Growing Market" released by Akamai, internet traffic in Indonesia experienced a 73 percent growth in the first quarter of 2020 (Pratama, 2020). It has increased to reach 139 percent in the second quarter. Seventy percent of smartphone users spend their time on social media, accessing podcasts, music, and playing games. The research was carried out by French technology company Criteo (Hadyan, 2020).

Workers who zoom meetings for a full day during working hours or even over working hours have the effect of "zoom fatigue." To avoid this fatigue, they use social media to choose several reasons and satisfaction, such as a source of entertainment and relaxation, spending time, interacting, and others.

Studies over the last ten years of using social media based on Uses and Gratification Theory have become the research material for the research literature. The research is focused on reasons for the uses and gratification of using social media. The selected journal articles use qualitative methods to be described in detail by the research results.

The first study was conducted by Gudelunas (2012), which examined the uses and gratification of network applications and websites that gay man widely uses. Based on the interviews with six gay man groups, this study discusses the needs and motivations that make gays access social networking sites and manage multiple online identities to satisfy their online activities.

The results showed that gay people used SNS to communicate with other gay. The platform chosen was used to talk about previously taboo things by culture, such as sexual practices. The need to demonstrate sexual desire was expressed through the selected SNS platform for sexual orientation satisfaction. Sites like Manhunt, BigMuscle.com, and Adam4Adam allow gay men to connect online and offline. Respondents are more likely to reveal that SNS contributes to sexual gratification.

Whiting \& William (2013), in an article entitled Why People Use Social Media: A Uses and Gratification Approach, apply Uses \& Gratification Theory on social media by conducting exploratory studies and in-depth interviews with 25 people. This study explores and discusses the use and satisfaction that users receive when using social media. This study identifies ten user uses and satisfaction when accessing social media. Namely: social interaction, information seeking, leisure time, entertainment, relaxation, communication utilities, convenience utilities, opinion expression, information sharing, and monitoring.

Furthermore, a study conducted by Dolan, Conduit, Fahy \& Goodman (2015) in Social Media Engagement Behavior: A uses and Gratification Perspective explains the role of social media content in shaping engagement or engagement on social media. This study is the development of a theoretical model of social media content in contributing to a deeper understanding of engagement in social media platforms based on the perspective of Uses and Gratification Theory.

This study provides a model that can form positive engagement based on Uses and Gratification Theory. The researchers explained the gratification typology of social media use, namely informational content, entertaining content, remunerative content, and relational content. The researcher then develops other variables: engagement, co-creation, positive contribution, consumption, dormancy, detachment, negative contribution, and co-destruction.

Researchers also found a podcast use and satisfaction study conducted by Perks \& Turner (2018) in an article entitled Podcasts and Productivity: A Qualitative Uses and Gratifications Study. This study integrates the use of old and new media by providing an extension of the existing typology. The result is the displacement of podcasts from other media, experiences, multitasking, and parasocial relationships and feeds the brain.

Athwal (2018) examines social media activities for luxury products based on Uses and Gratification Theory. The results show that social media accounts for luxury brands still display exclusivity. From observation to commenting and liking luxury brand content, user activity leads to the satisfaction of two types of needs: affective and cognitive. Two compelling needs that are fulfilled by luxury are aesthetic appreciation and entertainment. The mental need is satisfaction through the practical use of social media as a source of information. 
The latest journal article, Selecting Information Sources in Times of Crisis, which is relevant to researchers' research conditions, is the choice of media used by users during a pandemic (Bastari, 2020). The results showed that the three informants tended to use new media as an alternative to the official website of the Task Force because of the satisfaction of the new media.

This study will explore the Uses and Gratification Theory'sasic assumptions and typology based on the description above. The purpose of this study is to determine the uses and gratification of social media users to avoid zoom fatigue when working from home during the Covid-19 pandemic. Social media users use it as a means of fulfilling usability and satisfaction based on the media chosen. This study will describe the uses and gratification of using social media during WFH to avoid Zoom fatigue based on Computer-Mediated Communication Theory and Uses and Gratification Theory.

The basic assumptions and typology of gratification are the tools of analysis in the phenomena raised by researchers regarding Avoid Zoom Fatigue: The Uses and Gratifications of Social Media. What is new from this research is the description and explanation of the usefulness and satisfaction of using social media during WFH to avoid Zoom fatigue based on Uses and Gratification Theory. Media access choices and decisions are based on personal needs and values to be met.

\section{LITERATURE REVIEW}

\section{A. Computer-Mediated Communication (CMC) and New Media}

The development of information and communication technology is marked by the emergence of social media and computer-mediated communication (CMC). In this case, computer-mediated communication (CMC) is defined as communication through electronic or computer devices (McQuail, 2005).

Thurlow et al. (2004) cites Susan Herring (1996), CMC is communication between humans through computer instruments. CMC can also be a form of communication mediated by digital technology (Littlejohn \& Foss, 2013). Thurlow (2004) provides three focuses in CMC, namely communication, mediated, and computer. The basic assumption is a communication process mediated by computer technology connected to the internet for social interaction.

Furthermore, this computer-mediated communication differs from face-to-face communication directly. Two aspects distinguish CMC from face-to-face communication: verbal cues and extended time (Griffin, 2006). In contrast to face-to-face communication, which uses verbal symbols (through language) and nonverbal signs (through body gestures), while CMC uses signaling systems that exist in computer applications, for example, through emoticons (symbols in the form of text characters that represent expressions. humans in the online world). Communication that occurs in CMC also tends to be longer than face-to-face communication. Communicators in CMC cannot immediately understand the message's meaning because characters on the computer limit it.

\section{B. New Media}

This computer-mediated communication represents the rise of new media. In 1990, Mark Poster published his famous book, The Second Media Age, which marked a new period in which interactive communication technologies and networks, particularly the Internet, would transform society (Littlejohn \& Foss, 2013).

Littlejohn \& Foss (2013) quotes David Holmes as explaining the differences between the first and second media. According to Holmes, the first media were characterized by (1) centralized production; (2) one-way communication; (3) state control, for the most part; (4) reproduction of social stratification and inequality through the media; (5) fragmented mass audiences; and (6) social awareness building. While the second media can be described as (1) decentralized and user-generated (many to many or many to few); (2) two-way; (3) outside state control; (4) democratization; (5) promote individual awareness; and (6) individual-oriented.

Social media is a form of new media and a platform that allows users to represent themselves by sharing, interacting, communicating with other users, and forming social bonds virtually using the internet (Andlika, 2019). Kaplan and Haenlein (2010) define social media as an internet-based application built on the ideological and technical foundation of Web 2.0. According to Whiting \& Williams (2013), it gives the possibility of creating and exchanging content produced by users or users, moving fast and strong (Andlika, 2019).

\section{Uses and Gratification Theory}

One of the mass communication theories that are pretty popular until now is Uses and Gratification Theory. The Uses and Gratification Theory was first conceived in 1959, then formally introduced in 1973 by Elihu Katz, Jay G. Blumler, and Michael Gurevitch. There have also been previous research investigating why people use media. For example, Lazarsfeld in 1940 examined the attractiveness of radio programs (Rubin, 2009).

This theory focuses on the use of media chosen by the audience to meet their needs. Katz, Blumler, and Gurevitch (1973) argue that the audience is considered active, not passive recipients of messages. The audience then chooses to use 
specific media because it has the aim of fulfilling their satisfaction. So, this approach focuses on the audience rather than the message. According to him, instead of asking, "What do media do to people?", Katz et al. reversed the question to "What do people do with media?" (Griffin, 2006). The question, for Griffin, makes Uses and Gratification Theory still relevant to use and even inspires current research such as in social media.

This theory also explains when and how audiences become more active or less active in using media. The level of activity of each individual is not the same because it depends on the needs and goals determined by each. Rubin (2009) adds that the Uses and Gratification Theory aims to explain the psychological needs of why someone uses media and what motivates them to engage with the use of specific media to achieve certain satisfaction.

The main elements of Uses and Gratification include psychological and social environment, communication needs and motives, attitudes and expectations about media, functional alternatives to using media, communication behavior, and the consequences of audience behavior (Rubin, 2009). Katz, Blumer, and Gurevitch (1973) describe the research objectives of this theory, namely: (a) explain how audiences use media to satisfy their needs; (b) understand their behavioral motives; (c) identify the following functions or consequences of needs, motives, and behaviors.

\section{Assumptions Theory Uses and Gratification Theory}

There are five basic assumptions of Uses and Gratification Theory, namely: 1) the audience is considered active and goal-oriented when using the media; 2) the media compete with other sources of satisfaction of needs; 3 ) the audience determines the initiative to select and obtain media satisfaction; 4) the audience is aware of the interests and motives of media use, and 5) the assessment or orientation of media content is determined by the audience (Katz, Blumler and Gurevitch, 1973). Griffin (2006) also explains one of the theory's assumptions that the media will have a different effect on each individual.

2. Typology of Uses and Gratification

Katz, Blumer, and Gurevitch (1973) quoted Lasswell (1948), describing four media functions at the macrosociological level: monitoring, correlation, entertainment, and cultural transmission. Then the idea was developed by Wright (1960) at the macro and micro-sociological levels. Katz et al. Furthermore, the idea is that the media establish relationships through instrumental, affective, or integrative relationships - with various people (self, family, friends, nation).

McQuail, Blumler, and Brown (1972) categorized the types of television satisfaction. They relate background and social circumstances to the gratification sought and formulate a media-people interaction typology. McQuail and his colleagues observed that people are motivated to watch television for distraction - for escape and emotional release; personal relationships - for friendship and social utility; personal identity - for personal reference, exploration of reality and reinforcement of values; and surveillance - to obtain news and information (Littejohn, 2016).

There is one of the most comprehensive typologies of Uses and Gratification Theory described by Alan Rubin (2009), Instagram which breakdown eight typologies of motivation in the context of watching television, namely (1) filling spare time; (2) friendship; (3) escaping from pressure; (4) happiness; (5) social interaction; (6) relaxation; (7) information; and (8) joy (Griffin, 2018).

3. Uses and Gratification 2.0

As information and communication technology develops, Uses and Gratification Theory also develops. Many researchers have paid attention to using Uses and Gratification Theory. Stassen Previous research has shown that the satisfaction sought from social media can be anything, starting to seek information, promoting an organization, or even the opportunity to participate in a connected community of individuals (Stassen, 2010).

Uses and Gratification Theory has been widely used in various disciplines, but it can also help explain the use of new media. Uses and gratifications theory is relevant to social media because of its origins in the communications literature (Whiting \& Williams, 2013).

There is one of the most comprehensive typologies of Uses and Gratification Theory described by Alan Rubin. Rubin (1981) eight typologies of motivation in the context of watching television, namely (1) filling spare time; (2) friendship; (3) escape from pressure; (4) happiness; (5) social interaction; (6) relaxation; (7) information; and (8) joy (Griffin, 2006).

Whiting \& William (2013), in an article entitled Why People Use Social Media: A Uses and Gratification Approach, apply Uses \& Gratification Theory on social media by conducting exploratory studies and in-depth interviews with 25 people. This study explores and discusses the use and satisfaction that users receive when using social media. 
This study identifies ten user uses and satisfaction when accessing social media. Namely: social interaction, information retrieval, leisure time, entertainment, relaxation, communication utilities, convenience utilities, opinion expression, information sharing, and surveillance.

Research on media use (Karman, 2013) summarizes the reasons individuals use media. Opinions about the background or reasons for using the media can be grouped into three streams: 1) unfunctional flow, 2) bifunctional flow, and 3) four functional streams. The unfunctional school argues that the media only meets one type of need, for example, the need to escape (escapist desires), the need for play, or the need for social contact. The bifunctional school argues that the media fulfill two types of needs: fantasy \& escape needs, informational-educational, environmental monitoring, and surveillance-escape needs. Since then, the list of uses and gratuities has been extended, especially as new media emerge (e.g., video games and the internet).

\section{METHOD}

This study uses a qualitative approach with an experimental method to find or formulate problems from a phenomenon. This method also tends to have a loose structure to make it easier to find advanced research tasks in the future (Cooper and Schindler, 2008). Researchers used literature studies by studying related journals in the last ten years, using Uses and Gratification Theory as a knife of analysis. Furthermore, for further exploration, the researcher conducted in-depth semi-structured interviews via email and telephone with three informants from different backgrounds.

The category of informants is individuals working from home (WFH) during the Covid-19 pandemic, zoom meetings for an unlimited time, aged 25-45 years, and with a minimum position at the level of the supervisor from various industries. As an analytical tool, the researcher uses Uses and Gratification Theory to function as a framework to explore informants' answers regarding the reasons for choosing various social media for certain satisfaction to avoid zoom fatigue.

In this study, the qualitative comments of informants were analyzed using a typology of gratification (Whiting \& Williams, 2013). Based on a literature study conducted by researchers, journal articles provide an ideal picture of the reasons and goals of users using social media. This study identifies ten uses and gratuities in using social media. The ten uses and gratuities are social interaction, information retrieval, leisure, entertainment, relaxation, communication utilities, convenience utilities, opinion expression, information sharing, and monitoring/knowledge of others. After reading and reviewing the informants' comments, the researcher sorted out the uses and gratuities and discussed why people use social media.

\section{RESULTS AND DISCUSSION}

Interviews were conducted with three informants undergoing WFH with different occupational backgrounds: oil and energy companies, IT, and civil servants. Informants were selected based on their position in the company, which required attending virtual meetings beyond regular office hours. However, before researchers began to explore the reasons for the usefulness and satisfaction of using social media during WFH to prevent zoom fatigue, the researchers first asked the informants' experiences of undergoing virtual meetings during WFH.

"Since the activity restriction was implemented, our company has strictly implemented WFO and WFH. Even though I have several projects nearing the deadline to be completed, I am obliged to undergo WFH during the pandemic because I have comorbidities. As a result, virtual meetings were held to coordinate various parties to meet deadlines. However, because I am a field person, this virtual meeting feels tiring-management meeting in the morning to noon. Then there is a webinar that we must take part in during a pandemic, and the last is a meeting with the team that even exceeds office hours "(Informant 1, personal communication, January 11, 2021).

"WFH is not a holiday. In fact, it is busier than at the office. Virtual communication has more limitations than face communication" (Informant 2, personal communication, January 12, 2021).

"The tight virtual meeting schedule makes me confused when my child has to attend online school. Concentration is sometimes broken, even to the point of stress" (Informant 3, personal communication, January 12, 2021).

\section{Avoid Zoom Fatigue}

The Covid-19 pandemic forces companies to adapt to change while at the same time transforming and innovating by using information and communication technology to sustain their business. There are currently increasing efforts to move from conventional office settings to working from home (WFH) arrangements supported by information and communications technology, referred to as telecommuting, telework, or working from home (WFH).

WFH is often seen as the cause of unproductive work. However, WFH-related studies show that employees spend more time working, including g on virtual meetings, leading to zoom fatigue. To avoid fatigue due to this virtual meeting, users choose alternative media to meet their needs and satisfaction. One of them is by actively selecting content on social media. 
As a result of these changes, many employees have experienced increased fatigue and stress. Nonetheless, any type of stress needs to be handled with care and by individuals and their organizations providing appropriate and appropriate support (Michie, 2002).

Using Uses and Gratification Theory as the analysis tool, the three informants with different backgrounds are active recipients of the message. The three informants decided to use social media to fulfill their satisfaction, thus avoiding zoom fatigue. As Katz said, "What do people do with media?" So the three informants chose different types of social media with other goals.

One of them is very active in using social media, but another is less active. The level of activity of each individual is not the same because it depends on the needs and goals determined by each. Katz, Blumer, and Gurevitch (1973) describe how the user uses media to satisfy their needs; understand the motives for their behavior; and identifying the following functions or consequences of needs, motives, and behaviors.

\section{The Reasons People Use Social Media}

Based on literature studies and interviews that have been conducted, researchers describe the reasons for the uses and gratification of using social media to avoid zoom fatigue during the Covid-19 pandemic. The typology of Uses and Gratification Theory is explained by Alan Rubin (2009), Whiting \& Williams (2013), and Karman (2013). After reading and reviewing informants' comments, researchers sorted out the uses and gratuities and discussed why people use social media. The ten uses and gratification are social interaction, information retrieval, leisure, entertainment, relaxation, communication utilities, convenience utilities, expression of opinions, sharing of information, and surveillance/knowledge of others.

Informant 2 explains that to avoid zoom fatigue, we use social media as a source of entertainment - audience's satisfaction in using the media social based on motive specific. So, when the feeling is happy inside using media social followed by usage the media social over and over, so that is where it happens the satisfaction process using the media social.

"Watching podcasts can make me feel less bored when I continue to attend virtual meetings. I love watching the Close the Door podcast! Deddy Corbuzier. Nice enough to provide a diversion from the tiring routine of virtual meetings. I avoid heavy topics, but the content is overall quite entertaining" (Informant 2, personal communication, January 12, 2021).

A study conducted by Perks \& Turner (2018) reveals some of the uses and satisfaction of using podcasts. First, listening to podcasts replaces listening to the radio and watching television. Informant 1 confirmed that he only listens to the radio while in the car, while conventional television is rarely accessed because it uses video-on-demand more. The researcher entered into the other Uses and Gratification Theory assumptions, namely that the media compete with other sources of satisfaction of needs.

"Podcast content is more interesting because I can choose according to my mood at that time and can use a smartphone or laptop," said Informant 1. Another podcast advantage (Perks \& Turner, 2018) is that it allows multitasking. "Just like Youtube, which allows me to access while working" (Informant 1, personal communication, January 11, 2021).

Perks \& Turner (2018) also expanded gratification, which refers to old media related to the formation of parasocial relationships or ambivalence around the social aspects of listening to podcasts. The findings show that podcasts are fascinating because they help other listeners learn and do more.

Other informants confirmed that the reason for using social media is as a source of entertainment, such as streaming videos on Youtube, scrolling through Instagram, and viewing funny content on TikTok. Rubin (2009) added that the Uses and Gratification Theory aims to explain how a person's psychological reasons and motivation are using media to achieve certain satisfaction.

"In fact, in the middle of a virtual meeting when I am tired, I take a few minutes to look for funny content on TikTok. It may seem silly, but it is very entertaining. Because I have a teenage girl, she also always takes the initiative to fill in TikTok content. It's not bad to be moving, so we don't keep ongoing at the computer" (Informant 3, personal communication, January 12, 2021).

In the study of the Gudelunas (2012), researchers revealed that the purpose of accessing social media is for sexual needs. So, the purpose of using social media here is different in order to find entertainment or relaxation. Gay, through specific sites, openly express themselves in a sexual context.

The results of the interview also proved that informants use social media as a means for them to share knowledge. Social media such as Facebook or Twitter are rated as containers for them to increase knowledge. They also believe that the Facebook group is creating work productivity will be better. Besides, it is also the information conveyed in the Facebook 
group that is believed to help make better decisions in carrying out their work. Social media as a source of information.

For Informant 3, a pandemic has brought many lifestyle changes. The working from the home schedule is more flexible than working from the office because he is more at home to develop his farming hobby. The collection of plants is increasingly diverse, ranging from types of monstera, aglaonema, to caladium. Referring to this, the researcher argues based on Uses and Gratification Theory that even with similar media, each person's influence is not the same.

"While waiting for a break to another virtual meeting, because of my passion for planting during WFH, I accessed much planting content on Instagram and Youtube. I looked for information through the two platforms on planting the right way, for example, planting media, fertilizer, water needs, and sunlight. This hobby can also generate additional income during a pandemic because of certain collections that I sell" (Informant 3, personal communication, January 12, 2021).

The same thing was expressed by Informant 1 . He agrees that social media is a means to find information and reference products that will be purchased.

"My wife has an affinity for the interior. Usually, we discuss together to find a reference for the product to be purchased. I searched on the Pinterest platform looking for reference images. Then my wife compared the products sold online on Instagram" (Informant 1, personal communication, January 11, 2021).

The Uses and Gratification Theory explains that a person must identify their needs and make media choices (Katz et al., 1973). According to Katz et al., In Dainton, users are allowing themselves to choose media types, then allowing themselves to be influenced, changed, and influenced - or not.

The interview result also explained that The informants agreed on using social media to spend time. In between free time, they usually want to release boredom by looking for other activities. However, because conditions require activities only at home, access to social media is the best choice when they are bored. The choice of people to use the media is based on the gratuities they have. According to Katz, the key is which needs a person tries to fulfill when choosing the media.

"I also use Instagram while waiting for the next meeting. Usually I access gossip accounts like@lambe_turah. Ha ha ha ...." (Informant 3, personal communication, January 12, 2021).

"I use social media during boring meetings. The type of platform depends on the mood, usually Twitter and Instagram” (Informant 2, personal communication, January 12, 2021).

The presence of social media changes the way a person interacts and communicates. When activities are restricted during a pandemic, social media has become a medium for communicating and interacting virtually.

The Covid-19 pandemic is changing the way we interact because it is required to minimize face-to-face contact. As an alternative to interacting, social media can be an alternative to interact. For Informant 1, social media is chosen when not communicating face-to-face directly.

"Outside my family, I still rarely communicate directly, so I monitor family and friends through social media. I can know their activities and their health condition. Emotional involvement is usually expressed by commenting on their content posts" (Informant 1, personal communication, January 11, 2021).

"I enjoy reading stories of medical personnel and Covid-19 fighters on social media” (Informant 2, personal communication, January 12, 2021).

"This pandemic makes me more frequent comments and likes on posts that are spread on social media" (Informant 3, personal communication, January 12, 2021).

In their research, Dolan, Conduit, Fahy \& Goodman (2015) discussed the relationship between social media engagement with the perspective of Uses and Gratification Theory. Researchers assume that when users interact and provide comments or likes, it will shape engagement between users.

However, this social media presence has also had several negative impacts, especially on children. Children must participate in virtual learning during a pandemic to make computers, cellphones, or other electronic devices readily available. Therefore, parental assistance is needed to carry out supervision.

Several studies mention the harmful effects of social media use. Muhammad (2019) conducted a study that social media like Instagram is addictive towards children and adolescents. He uses for 2 hours and more likely to experience poor mental and psychological stress. Even in research conducted by Whiting \& Williams (2013), social media is also used to spy or observe what other people are doing. Even the respondents also admitted that what social media does is spying on their children. 
"I like to observe Instagram monitor what is posted on social media" (Informant 3, personal communication, January 12, 2021).

\section{CONCLUSION}

Through research that has been conducted on the use of social media to avoid zoom fatigue as a means of fulfilling usability and satisfaction while undergoing WFH during a pandemic, researchers have found that there are several reasons for fulfilling the utility and pleasure of using social media in avoiding zoom fatigue.

Researchers used several literature studies and conducted interviews with informants, which revealed the use of social media to avoid zoom fatigue, namely social interaction, information retrieval, leisure, entertainment, relaxation, communication utilities, convenience utilities, expression of opinions, sharing of information, and surveillance. Knowledge of others.

In this study, informants as active users of social media choose according to specific uses and satisfaction. Three pieces of information reveal that social media is used to avoid stress or fatigue when undergoing virtual meetings at working from home (WFH) or zoom fatigue. The media used are various, from Instagram, Youtube, Twitter, Podcast, and Pinterest. Informants do not have a better preference because all platforms are used to achieve the desired satisfaction.

The researchers suggest that further research can focus on one type of social media and conduct more in-depth interviews due to the research limitations. Researchers hope that the results of this study can fill the shortcomings of existing research related to the use and gratification of social media based on Computer-Mediated Communication and Uses and Gratification Theory. Besides that, it can also contribute knowledge to practitioners who are content creators, marketing agencies, online shop owners to optimize content to get high user engagement.

\section{REFERENCES}

[1] Andlika, Vienty. (2019). Influence of anonymity toward frequency of online hate speech content analysis of instagramaccount@prabowomondardo. Pengaruh anonimitas terhadap frekuensi online hate speech analisis isi akun instagram@prabowomondardo. Thesis. Jakarta. Universitas Indonesia.

[2] Athwal, N., Istanbulluoglu, D. and McCormack, S.E. (2019). The Allure of Luxury Brands'Social Media Activities: A Uses and Gratifications Perspective. Information Technology \& People, Vol. 32 No. 3, pp. 603-626. https://doi. org/10.1108/ITP-01-2018-0017

[3] Bastari, Andi Amiratania (2020). Selecting Information Sources in Times of Crisis. Jurnal Komunikasi Indonesia, Vol 9, No 2, 78-88, https://doi/org/10.7454/jki.v9i2.12769

[4] CNN Indonesia. (2020). Study on WFH: Longer Work and More Meetings. Studi soal WFH: Kerja Lebih Panjang dan Rapat Lebih Banyak. Retrieved from https:/www.cnnindonesia.com/gaya-hidup/20200901102717-284-541464/ studi-soal-wfh-kerja-lebih-panjang-dan-rapat-lebih-banyak

[5] Cooper, D., \& Schindler, P. (2008). Business research methods (10th ed.). New York, McGraw-Hill/Irwin.

[6] Detik.com. (2020). Add 10 Thousand More! RI Corona cases as of January 9 became 818,386. Tambah 10 Ribu Lagi! Kasus Corona RI Per 9 Januari Jadi 818.386. Retrieved from https://news.detik.com/berita/d-5327211/ tambah-10-ribu-lagi-kasus-corona-ri-per-9-januari-jadi-818386

[7] Dolan, Rebecca \& Conduit, Jodie \& Fahy, John \& Goodman, Steve. (2015). Social Media Engagement Behaviour: A Uses and Gratifications Perspective. Journal of Strategic Marketing. 24. 10.1080/0965254X.2015.1095222.

[8] Griffin, Emory A. (2006). A First Look at Communication Theory 6th Edition. New York. McGraw the -Hill Education.

[9] Gudelunas, D. (2012). There's an App for that: The Uses and Gratifications of Online Social Networks for Gay Men. Sexuality \& Culture. 16, 347-365. https://doi.org/10.1007/s12119-012-9127-4

[10] Government Regulation regarding Large-Scale Social Restrictions in the Context of Accelerating the Handling of Corona Virus Disease 2019 (COVID-19). Peraturan Pemerintah (PP) tentang Pembatasan Sosial Berskala Besar dalam Rangka Percepatan Penanganan Corona Virus Disease 2019 (COVID-19).

[11] Hadyan, Rezha. (2020). It Turns Out That Indonesians Spend a Lot Of Time On Social Media. Ternyata, Masyarakat Indonesia Banyak Habiskan Waktu di Media Sosial. Retrieved from https://lifestyle.bisnis.com/ $\mathrm{read} / 20201001 / 220 / 1299346 /$ ternyata-masyarakat-indonesia-banyak-habiskan-waktu-di-media-sosial

[12] Katz, E., Blumler, J., \& Gurevitch, M. (1973). Uses and Gratifications Research. The Public Opinion Quarterly, 37(4), 509-523. Retrieved from http://www.jstor.org/stable/2747854

[13] Karman, Karman. (2013). Research on Media Use and Its Current Development. Riset Penggunaan Media Dan Perkembangannya Kini. Jurnal Studi Komunikasi dan Media, vol. 17, no. 1, pp. 93-112, doi:10.17933/ jskm.2013.1701 
[14] McQuail, D. (2005). Mass Communication Theory. London: Sage Publications.

[15] Michie, Susan. (2002). Causes and management of stress at work. Occupational and Environmental Medicine 59(1):67-72 DOI: 10.1136/oem.59.1.67

[16] Nadler, Robby. (2020). Understanding “Zoom fatigue”: Theorizing Spatial Dynamics as Third Skins in ComputerMediated Communication. Elsevier. https://doi.org/10.1016/j.compcom.2020.102613

[17] P. Rana, Sujeet K. Sharma, Nitin Upadhyay (2020). Impact of COVID-19 Pandemic on Information Management Research and Practice: Transforming Education, Work, and Life. International Journal of Information Management, Volume 55. https://doi.org/10.1016/j.ijinfomgt.2020.102211

[18] Perks, Lisa Glebatis \& Turner, Jacob S.. (2019). Podcasts and Productivity: A Qualitative Uses and Gratifications Study. Mass Communication and Society, 22:1, 96-116, DOI: 10.1080/15205436.2018.1490434

[19] Pratama, Kevin Rizki. (2020). Indonesia's Internet Traffic Soars. Trafik Internet Indonesia Melonjak. Retrieved from https://tekno.kompas.com/read/2020/12/21/11410087/trafik-internet-indonesia-melonjak?utm source=LINE\&utm_medium=today\&utm_campaign=messaging

[20] Rubin, Alan. (2009). Uses-And-Gratifications Perspective on Media Effects. Media Effects: Advances in Theory and Research.

[21] S. Shyam Sundar \& Anthony M. Limperos. (2013). Uses and Grats 2.0: New Gratifications for New Media. Journal of Broadcasting \& Electronic Media, 57:4, 504-525, DOI: 10.1080/08838151.2013.845827

[22] Stassen, W. (2010). Your News in 140 Characters: Exploring The Role of Social Media in Journalism. Global Media Journal, 4(1), 1-16.

[23] Stephen W. Littlejohn \& Karen A. Foss. (2013). Teori Komunikasi Edisi 9. Jakarta: Penerbit Salemba Humanika

[24] Stephanie, Conney. (2020). Pandemi Covid-19, Pendapatan Zoom Naik Hampir 4 Kali Lipat. Retrieved from https://tekno.kompas.com/read/2020/12/01/18120027/pandemi-covid-19-pendapatan-zoom-naik-hampir-4-kalilipat

[25] Thurlow, Crispin., Lengel, Laura., Tomic, Alice. (2004). Computer Mediated Communication. SAGE Publications

[26] Van der Lippe, T., and Lippényi, Z. (2020), Co $\square$ Workers Working From Home and Individual and Team Performance. New Technology, Work and Employment, 35: 60-79. https://doi.org/10.1111/ntwe.12153

[27] Walther, J. B. (1996). Computer-Mediated Communication: Impersonal, Interpersonal, and Hyperpersonal Interaction. Communication Research, 23(1), 3-43. https://doi.org/10.1177/009365096023001001

[28] Whiting, Anita \& Williams, David. (2013). Why People Use Social Media: A Uses and Gratifications Approach. Qualitative Market Research. 16. 10.1108/QMR-06-2013-0041.

[29] Yogesh K. Dwivedi, D. Laurie Hughes, Crispin Coombs, Ioanna Constantiou, Yanqing Duan, John S. Edwards, Babita Gupta, Banita Lal, Santosh Misra, Prakhar Prashant, Ramakrishnan Raman, Nripendra P. Rana, Sujeet K. Sharma, Nitin Upadhyay. (2020). Impact of COVID-19 pandemic on information management research and practice: Transforming education, work, and life. International Journal of Information Management, Volume 55. https://doi.org/10.1016/j.ijinfomgt.2020.102211. 
